\title{
REFORMASI SISTEM PERADILAN PIDANA DALAM RANGKA PENANGGULANGAN MAFIA PERADILAN
}

\author{
J. Pajar Widodo \\ Fakultas Hukum Universitas Lampung \\ E-mail: Wiedjar@yahoo.co.id
}

\begin{abstract}
The purpose of reformation criminal justice system is to strengthen the principle of independence and impartiality criminal justice. Strengthening of independence principle and impartiality criminal justice is done in the process of constitutional amendment and legislation. The reformation of the criminal justice system includes the substance of the law of one roof system design of judicial power that culminated in the Supreme Court. The strengthening of the principle of independence and impartiality criminal justice is to overcome judicial mafia practice that equipped by law reformation culture to uphold the value system, which are values and principles due process of law.
\end{abstract}

Keyword: Judicial reform, independence, judicial mafia

\begin{abstract}
Abstrak
Tujuan reformasi sistem peradilan pidana adalah untuk memperkuat prinsip independensi dan imparsialitas peradilan. Penguatan prinsip independensi dan imparsialitas peradilan dilakukan dalam proses legislasi dalam amandemen konstitusi dan peraturan perundang-undangan. Reformasi sistem peradilan meliputi substansi hukum yaitu desain one roof system kekuasaan kehakiman yang berpuncak pada Mahkamah Agung. Penguatan prinsip independensi dan imparsialitas peradilan merupakan sarana untuk menanggulangi praktik mafia peradilan, yang dilengkapi dengan reformasi kultur hukum untuk menegakkan sistem nilai, yaitu nilai-nilai dan prinsip-prinsip due process of law.
\end{abstract}

Kata kunci : Reformasi peradilan, independensi, mafia peradilan

\section{Pendahuluan}

Fungsi ideal pengadilan sebagai institusi penegak hukum yang bertugas menegakkan hukum dan keadilan, serta menjamin perlindungan hak asasi manusia, pada saat ini mengalami keterpurukan, yang disebabkan karena adanya rekayasa, diskriminatif dan ketidakadilan sebagai hasil korupsi pengadilan (judicial corrupttion), yang populer disebut mafia peradilan. ${ }^{1}$ Mafia peradilan merupakan bentuk kegagalan peradilan sebagai sarana mencari keadilan, telah menjadi pola tindakan menyimpang dalam proses peradilan pidana.

Praktik mafia peradilan merupakan perbuatan melawan hukum yang merusak sendi-

\footnotetext{
Lihat arti isitlah mafia peradilan pada Donny Daradono, "Uang, Ideologi, Jabatan dalam Mafia Peradilan, Reduksi terhadap The Political", Renai, J urnal Kajian Politik Lokal dan Studi Humaniora. Tahun VII No 2. Tahun 2007. Yayasan Percik. Salatiga. hlm. 5.
}

sendi independensi dan imparsialitas pengadilan, karena rekayasa hukum yang dilakukan sindikat mafia peradilan melanggar prinsip-prinsip due process of law dalam proses peradilan pidana. Akibat langsung dari praktik mafia peradilan menimbulkan diskriminasi perlakuan terhadap pencari keadilan berdasarkan pertimbangan rasionalitas-pragmatisme, bertumpu pada kekuatan "uang dan kekuasaan", mengabaikan prinsip penegakan hukum pidana yang adil.

Proses peradilan pidana dijalankan berdasarkan pertimbangan "transaksional" antar para pihak yang mempunyai kekuatan ekonomi dengan kekuasaan publik yaitu penengak hukum, menghasilkan penegakan hukum pidana yang tidak adil dan diskriminatif. Praktik mafia peradilan menjadi catatan buruk bagi pengadilan karena merusak integritas pengadilan, bahkan ada sebagian hakim yang menganggap tugasnya sebagai profit-driven industry atau ben- 
tuk usaha yang diarahkan untuk mendapatkan keuntungan. ${ }^{2}$ Jika putusan hakim sudah terkontaminasi kepentingan materi, maka putusan tidak berpihak pada keadilan, sehingga masyarakat tidak percaya kepada pengadilan. Ketidakpercayaan masyarakat terhadap pengadilan bisa berupa main hakim sendiri (eigenrichting) atau penghinaan terhadap pengadilan (obstruction of justice). ${ }^{3}$

Penegakan hukum pidana terdistorsi rasionalitas transaksi ekonomi, sehingga proses peradilan pidana tidak lebih dari lembaga yang berusaha mencari "pembenaran (justification), yang seharusnya pengadilan mencari" kebenaran (truth) dan keadilan (justice). Praktik mafia peradilan semakin kreatif dalam membuat pembenaran proses hukum yaitu dengan membentuk tim lobi sebagai bagian strategi pembelaan perkara tim pengacara untuk merekayasa proses hukum. Pembelaan perkara pidana tidak lagi dibangun atas dasar argumentasi hukum yang logis, te-tapi berdasarkan kekuatan lobilobi dan pendekatan ke berbagai pihak yaitu penyidik, penuntut umum atau hakim untuk memenangkan perkara, meringankan pidana atau membebaskan terdakwa kliennya. Bahkan kekuatan mafia peradilan juga telah merambah ke komunitas akademik, dengan cara "mengatur" keterangan hukum ahli saksi dalam pembuktian memberikan keterangan di muka pengadilan.

Proses peradilan pidana saat ini menunjukkan kaburnya orientasi para penegak hukum antara usaha menegakkan hukum dan menegakkan keadilan. Tujuan utama dalam berperkara bukan untuk menegakkan hukum dan keadilan, tetapi untuk memenangkan perkara. Pergeseran orientasi para penegak hukum dalam peradilan pidana yang lebih menekankan rasionalitas pragmantis, mendistorsi nilai etis moral pe-

\footnotetext{
Noor Aziz Said, "Rekonstruksi Pertanggungjawaban Pidana terhadap Tindak Pidana Korupsi APBD yang Dilakukan Anggota Dewan", Jurnal Dinamika Hukum. Volume 11 Edisi Khusus. Februari 2011. Fakultas hukum UNSOED, Purwokerto, hlm. 131-132.

3 Nurhayati Mardin, "Makna Kepala Putusan Pengadilan: Keadilan Berdasarkan Ketuhanan Yang Maha Esa (Tinjauan Rechtphilosopie)", J urnal Hukum Aktualita. Vol II No 3 Desemebr-Maret 2007, Fakultas Hukum Universitas Tadulako, hlm. 279.
}

negakan hukum dan keadilan, kemudian dibelokkan pada juga berkaitan dengan problem konseptual yuridis. Paradigma positivime hukum yang mewarnai hukum modern, mengedepankan fungsi peraturan perundang-undangan, cenderung terikat pada formalisme dan prosedural peraturan perundang-undangan, kurang menggali nilai-nilai substansial dari hukum, sehingga menimbulkan kritik tajam. Kritik terhadap karakter hukum modern yaitu bagimana keluar dari formalisme yang membabi-buta dan bagaimana mendamaikan prinsip legalitas hukum dengan moralitas. ${ }^{4}$

Konsep hukum sebagai teks undang-undang dalam penerapannya bertolak dari silogisme metodologis, terstruktur dalam silogisme deduktif-logis, sehingga subjektivitas nilai etismoral terperangkap dalam logika deduktif-logis. Putusan pengadilan tidak lebih sebagai hasil konklusi dari deduksi teks undang-undang terhadap peristiwa konkrit dalam suatu kasus, sehingga pertimbangan adil dan tidak adil menjadi sangat nisbi, karena argumentasi hukum hakim berakhir dalam konklusi logika deduksi yang lebih menekankan kepastian hukum, mengabaikan nilai-nilai moral keadilan. ${ }^{5}$ Peradilan seharusnya menjalankan fungsi kemasyarakatan, dengan menggerakan pengadilan untuk menyelesaikan masalah masyarakat, tidak sebatas menerapkan peraturan perundangan yang menekankan kepastian hukum. ${ }^{6}$

Berdasarkan karakteristik yang sedemikian, ${ }^{7}$ maka bisa di pahami secara konseptual, mengapa praktik mafia peradilan bisa lolos dari penilaian sebagai perbuatan melanggar hukum. Para penegak hukum berlindung dalam aras positivisme hukum, bertolak dari logika rasional,

\footnotetext{
C. Maya Indah S, "Refleksi sosial atas Kelemahan hukum Modern, suatu diseminasi hukum tradional dalam citra hukum Indonesia", Jurnal Masalah-Masalah Hukum, Fakultas Hukum Universitas Diponegoro, Semarang, Vol 103 No. 37 tahun 2008, hlm. 164.

5 M. Syamsudin, "Faktor-Faktor Sosio-legal yang Menentukan Dalam penanganan Perkara Korupsi di Pengadilan", J urnal Media Hukum. UMJ . Yogyakarta. 2010, hlm. 408.

6 Edy Rifai, 2010, "Peran Hakim Dalam Penemuan Hukum dan Menciptakan Hukum Pada Era Reformasi", Jurnal IImu Hukum "Praevia" Fakultas Hukum Unila. Vol. 4. No. 1 tahun 2010, hlm. 49.

7 Anis Ibrahim, "Hukum Progresif: Solusi atas Keterpurukan Hukum Indonesia", J urnal Hukum Progresif, Vol 2 No. 1/ April 2006 PDIH Undip, Semarang.
} 
membangun argumentasi rasional dalam struktur logis-sistematis, antara lain dalam rentang minimal-maksi-mal pidana, jenis pidana yang menguntungkan terdakwa. Terdapat kecenderungan umum (mainstream) para hakim mengikuti pola pikir legal positivism berupa pola pikir legal formal mengesampingkan nilai etis-substansial hukum. ${ }^{8}$

Argumentasi hukum yang dibangun hakim, tidak tampak cacat hukum serta dapat di pertanggungjawabkan lepas dari produk putusan kolutif. Bahkan putusan pengadilan hanya bisa dikoreksi secara internal dalam struktur vertikal proses hukum selanjutnya mulai dari upaya hukum banding di Pengadilan Tinggi, kasasi dan penunjauan kembali di Mahkamah Agung. Putusan kolutif yang penuh rekayasa, dengan demikian tidak terjangkau dari koreksi atau eksaminasi eksternal pengadilan, khususnya masyarakat yang menjadi tujuan dari produk putusan pengadilan. Semangat untuk memberantas praktik korupsi di pengadilan hanya menyalahkan sistem yang ada, kurang berorientasi pada pengawasan kinerja profesionalitas penegak hukum, sehingga terhalang perilaku penegak hukum yang menyalahgunakan kekuasaan (abuse of power) yang tersamar dalam legalitas kewenangan penegak hukum ${ }^{9}$

Persoalan konseptual yang menyangkut struktur penegakan hukum pidana, bersumber dari sistem penegakan hukum yang dibangun berdasarkan desain konstitusional. Pasca amandemen ke-3 UUD 1945, yang kemudian diikuti terbitnya UU No. 48 Tahun 2009 tentang Kekuasaan Kehakiman sebagai peraturan pelaksana, terdapat koreksi pada 'Kekuasaan Kehakiman'. Desain kekuasaan kehakiman dalam UUD 1945 Amandemen ke-3, sebagaimana tersebut dalam Bab IX, meliputi Mahkamah Agung dan peradilan dibawahnya, Mahkamah Konstitusi dan Komisi Yudisial. Keberadaan Komisi Yudisial dalam

8 M. Syamsudin, "Rekonstruksi Pola Pikir Hakim dalam Memutus Perkara Korupsi Berbasis Hukum Progresif" J urnal Dinamika Hukum, Vol 11 No 1 J anuari 2011, Fakultas Hukum UNSOED Purwokerto, hlm. 10

9 Jawade Hafidz, "Sistem Pertanggungjawaban Perkara Korupsi Dalam Percepatan Penyelematan Keuangan Negara", J urnal Dinamika Hukum. Vol 11 Edisi Khusus, Fakultas Hukum UNSOED, Purwokerto, Februari 2011. hlm. 116
Bab IX bersama-sama dengan Mahkamah Agung dan Mahkamah Konstitusi, pada dasarnya didesain sebagai lembaga yang melaksanakan kekuasaan kehakiman, yaitu sebagai supporting element berpasangan dengan Mahkamah Agung dan Mahkamah Konstitusi, untuk memperkuat prinsip kekuasaan kehakiman yang independen dan imparsial, guna menegkkan hukum dan keadilan.

Derivasi persoalan konseptual kekuasaan kehakiman selanjutnya adalah legalitas dan kedudukan lembaga penyidikan dan penuntutan yang tidak jelas. Apabila politik hukum kekuasaan kehakiman berorientasi pada upaya memperkuat independensi dan imparsialitas peradilan pidana, sudah pada tempatnya, dilakukan evaluasi dan koreksi secara konseptual, bahwa keseluruhan penegak hukum dalam peradilan pidana adalah lembaga penegak hukum kekuasaan kehakiman yang bersandar konstitusi. Penyidik dan penuntut umum secara legal formal bukanlah bagian dari kekuasaan kehakiman karena masuk dalam ranah kekuasaan eksekutif, tetapi secara fungsional bersama-sama dengan pengadilan melaksanakan kekuasaan kehakiman (rechterlijke macht). Pengertian sistem peradilan pidana, secara konseptual sering dipahami secara keliru karena komponen pendukungnya secara normatif, terdiri dari sub sistem penyidikan, penuntutan, pengadilan dan pelaksana pidana. Kebijakan formulasi lembaga pendukung sistem peradilan yang bersifat parsial, yang menempatkan penyidikan dan penuntutan di luar kekuasaan kehakiman, akan tetapi menjalankan kekuasaan bersama pengadilan, menimbulkan kelemahan koordinasi dan pengawasan kekuasaan kehakiman. Desain kekuasaan kehakiman pasca amandemen ke-3 UUD 1945, masih bersifat parsial dan belum integral dalam keseluruhan kekuasaan peradilan.

Keseluruhan proses peradilan pidana dijalankan atas prinsip kekuasaan kehakiman, tetapi penyidik, penuntut umum dan pelaksana eksekusi putusan pengadilan berada dalam ranah kekuasaan eksekutif. Problem hukum dari kebijakan sistem peradilan pidana yang bersifat parsial menyebabkan lemahnya prinsip independensi dan imparsialitas peradilan dan le- 
mahnya pengawasan internal dan eksternal dari masyarakat. Kelemahan ini menjadi kendala sistematis penanggulangan mafia peradilan. Permasalahan penanggulangan mafia peradilan berkaitan dengan masalah apakah ada problem konseptual-juridis dan bagaimana reformasi sistem peradilan pidana yang integral untuk memperkuat independensi peradilan.

\section{Mafia Peradilan dan Permasalahannya}

Terdapat empat bentuk modus operandi aktivitas "mafia peradilan yang terjadi dalam proses peradilan. Pertama, penundaaan pembacaan putusan oleh majelis hakim. Hakim akan menghindar bila ditanyakan alasan penundaan, dengan menyatakan, "kalau ditanyakan ke panitera akan mendapatkan sinyal, bahwa hakim minta sesuatu". Kedua, hakim sengaja tidak memberi penilaian atas suatu fakta atau bukti tertentu, sehingga putusan pengadilan ringan, bahkan putusan bebas. Ketiga, manipulasi penerapan peraturan perundang-undangan yang tidak sesuai dengan fakta hukum yang terungkap di persidangan. Majelis hakim mencari peraturan hukum sendiri, sehingga fakta hukum ditafsirkan berbeda, akhirnya dakwaan tidak terbukti, putusan bebas. Keempat, pencarian peraturan perundang-undangan oleh majelis Hakim, agar dakwaan Jaksa beralih ke pihak lain, terutama pada kasus korupsi, dibuat agar terdakwa melakukan hal tersebut atas perintah atasan, sehingga terdakwa dibebaskan.

Modus operandi praktik mafia peradilan semakin rapi dan melibatkan banyak pihak, dengan peranan yang berbeda-beda, sehingga bersifat sistematis seperti sindikat. ${ }^{10}$ Secara umum praktik mafia peradilan di persidangan pengadilan meliputi: pertama, permintaan uang jasa, dalam hal ini pengacara harus menyiapkan uang ekstra bagian registrasi perkara; kedua, penentuan majelis hakim, dilakukan sendiri atau meminta jasa panitera pengadilan; dan ketiga, negosiasi putusan pengadilan, sudah ada kordinasi sebelumnya tentang tuntutan Jaksa Penuntut Umum yang berujung pada

10 Busryo Muquddas. Mafia Peradilan Berjalan Sistemik. Lihat dalam http:// beritasore. com/2009/ 07/ 16/ mafiaperadilan. Diunduh 12 juli 2011. vonis hakim, terjadi negosiasi tawar menawar antara hakim, jaksa, pengacara tentang hukuman dan uang yang harus dibayarkan.

Praktik mafia peradilan pada tahap pemeriksaan di Penyidikan (kepolisian) dan Penuntut Umum, tidak jauh dari modus opreandi di pengadilan yang mengarah pada perbuatan mengkondisikan proses hukum sebagai ruang menarik keuntungan materi, dengan mengabaikan hukum. Di Kepolisian, ${ }^{11}$ dibedakan pada tahap penyelidikan, modus operandi meliputi: pertama, pemintaan uang jasa, laporan ditindaklanjuti setelah (pelapor) menyerahkan laporan uang jasa; dan kedua, penggelapan perkara, penanganan perkara dihentikan setelah setelah ada kesepakatan membayar sejumlah uang jasa kepada polisi (penyelidik). Pada tahap penyidikan, modus operandinya meliputi: pertama, negosiasi perkara, tawar menawar pasal yang dikenakan terhadap tersangka dengan imbalan uang yang berbeda-beda, menunda surat pemberitahuan dimulainya penyididikan (SDPD) kepada kejaksaan; dan kedua, pemerasan oleh polisi, tersangka dianiaya terlebih dahulu agar mau koorporatif dan menyerahkan uang, mengarahkan kasus lalu menawarkan jaIan damai. Pengaturan ruang tahanan, penempatan di ruang tahanan menjadi alat tawarmenawar. ${ }^{12}$

Mafia peradilan di kejaksaan meliputi: pertama, pemerasan, penyidikan diperpanjang untuk merundingkan uang damai, surat panggilan sengaja tanpa status " saksi" atau "tersangka", pada ujungnya saat pemeriksaan akan di-mintai uang agar statusnya tidak "tersangka"; kedua, negosiasi status, perubahan status tahanan tersangka menjadi alat tawar menawar; ketiga, pelepasan tersangka, melalui surat perintah penghentian penyidikan (SP3) dengan sengaja membuat dakwaan yang kabur (obscuur libel) sehingga terdakwa divonis bebas;

11 M. Edi Santoso, "Kebijakan Pidana Dalam Proses Gerakan Sosial Melalui Sistem Peradilan Pidana terhadap Mafia Peradilan", Jurnal Gema, Vol XVIII. No 33 Tahun 2005, Universitas Islam Batik, Surakarta, hlm. 104.

12 Wahyu Wiriadinata, "Masalah Mafia Peradilan dan Korupsi di Indonesia", J urnal Syiar Hukum, Vol XIL No 1 Maret 2010, Fakultas Hukum Universitas Islam Bandung. hlm. 54 
keempat, penggelapan perkara, berkas perkara dihentikan jika memberikan sejumlah uang, saat dilimpahkan ke kejaksaan, polisi mengatakan "sudah ada yang mengurus", sehingga tidak tercatat dalam register; kelima, negosiasi perkara, proses penyidikan yang diulur-ulur merupakan isyarat agar keluarga tersangka menemui Jaksa, bisa melibatkan calo perkara yang berasal dari kejaksaan, anak pejabat, pengacara rekanan jaksa, berat-ringannya dakwaan menjadi alat tawar menawar; dan keenam, pengurangan tuntutan, tuntutan pidana bisa diringankan bila terdakwa memberikan sejumlah uang, Berita Pemeriksaan (BAP) dibocorkan saat penyidikan, Pasal yang disangakakan juga dapat diperdagangkan.

Modus operandi mafia peradilan yang digambarkan di atas, tergambar pula ada Kasus Gayus Tambunan Pegawai Direktorat Jendral Pajak Depkeu di Jakarta. Proses penanganan kasus Gayus sejak tahap penyidikan, penuntutan sampai putusan penegadilan ditemukan kejanggalan. Pada tahap penyidikan dan Prapenuntutan, Pasal pelanggaran hukum yang diterapkan penyidikan, kumudian dikoreksi Penuntut Umum, sudah ada gejala "rekayasa". Semestinya tersangka dijerat tiga pasal yaitu pelanggaran tindak pidana korupsi, pencucian uang dan penggelapan. Hasil pra penuntutan Tersangka "diarahkan" pada pelanggaran Pasal pencucian uang dan penggelapan, kemudian Penuntut Umum membuat Dakwaan Alternatif, pelanggaran tindak pidana pencucian uang atau peng-gelapan. Hasil pembuktian persidangan di PN. Tangerang, terdakwa divonis bebas, karena tidak terbuktinya dakwaan, serta sudah ada pengembalian uang dari terdakwa kepada saksi Andi Kosasih. Putusan Kasus Gayus membuat bingung masyarakat, mengapa Jaksa sembrono menyusun dakwaan, hingga tidak terbukti, mengapa hakim bisa keliru membuat putusan? Mungkin inilah yang disebut mafia peradilan.

Putusan pembebasan Gayus membuat kontroversi di masyarakat, kemudian Kapolri membentuk Tim Penyidik Independen, hasilnya penyidik kasus Gayus menjadi tersangka kasus suap, Kejagung membentuk Tim Eksaminasi, hasilnya Tim J aksa Peneliti melakukan ketidak- cermatan yang disengaja, seharusnya dakwaan disusun secara kumulatif yaitu tindak pidana korupsi, pencucian uang dan penggelapan, kenyataan disusun alternatif tindak pidana pencucian uang dan penggelapan. Vonis bebas, memaksa Komisi Yudisial memanggil Hakim Ketua Sidang PN Tangerang. Hasilnya, Hakim Asnun mengaku mendapatkan uang suap dari Gayus lima puluh juta rupiah. Penuntut umum dan Hakim kasus Gayus, saat ini telah menjadi Terdakwa dan dipidana di pengadilan dan di pidana.

Praktik mafia peradilan pada umumnya menggunakan dan menyamarkan "kewenangan/ kekuasaan hukum", sebagai dalih untuk melakukan praktik suap menyuap. Pemegang kekuasaan judisial dengan berdalih kekuasaan judisial yang bebas dan independen, dalam ketertupan proses hukum melakukan penyimpangan hukum ditukar dengan keuntungan materi pribadi. ${ }^{13}$ Akibat korupsi peradilan, kewibawaan lembaga peradilan meluncur kebawah, sebagaimana dinyatakan Para Cumaraswani, Pelapor kasus pada Perserikatan Bangsa-bangsa yang menyimpulkan bahwa korupsi peradilan di Indonesia adalah salah satu yang terburuk di dunia, yang hanya mungkin disamai oleh Meksiko, negara yang mayoritas rakyatnya tidak terkejut sama sekali dengan fenomena korupsi peradilan. ${ }^{14}$

Fenomena praktik suap menyuap dalam mafia peradilan pada dasarnya merupakan bentuk pertukaran kekuasaan, yaitu barter antara "kekuasaan hukum" yang dipegang penegak hukum dengan "kekuasaan materi/uang" yang dipegang para pencari keadilan (tersangka/terdakwa). Pertukaran kekuasan tersebut, bisa dijelaskan dengan teori pertukaran (exchange theory) dari Peter M. Blau, yang bertolak dari pertukaran kekuasaan. Pertukaran kekuasaan terjadi lebih massif apabila ada kesenjangan penguasaan "kekuasaan" antara "powerful" dengan "powerless". Carut marut penegakan

\footnotetext{
13 Bambang Wijoyanto, "Harmonisasi Peran Penegak Hukum Dalam Pemberantasan Korupsi", J urnal Legsilasi Indonesia, Vol 4 No. 1 Maret 2007. Direktorat J enderal Perundang-undangan Depkumham RI, hlm. 7.

14 Noor Azis Said. op, cit, hlm. 132
} 
hukum pidana, yang dimulai dari rusaknya komponen kultur, kemudian merambah pada komponen struktur penegakan hukum. Pengertian struktur penegakan hukum sebagaimana dimaksud Friedman sebagai "... the structure of the system is it skeletal frame work, it is the permanent shape, the institutional body of the system, the tough, rigid bones that keep the process flowing within bounds", adalah serangkaian syarat dan prosedur hukum dalam keseluruhan proses peradilan pidana, dengan standar yang telah ditentukan. Misalnya dalam pedoman penyelidikan dan penyidikan di kepolisian. Prosedur Tetap Penuntutan di Kejaksaan, Protap Rencana Dakwaan (Rendak), Protap Rentut, yang sudah baku. Pelangaran aspek Struktur yang menyebabkan carut marut penegakan hukum pidana, terdapat dua aspek, yaitu rusaknya sistem prosedur (procedural/fisical system), seperti Protap di atas dan sistem nilai (value system) yaitu asas-asas penegakan hukum due process of law, seperti asas persamaan di depan hukum.

Terungkapnya beberapa kasus suap-menyuap di lembaga peradilan pidana yang melibatkan jajaran penegak hukum dalam proses peradilan pidana, sebagai bentuk Judicial Corruption (korupsi peradilan), menjadi titik balik dan anomali reformasi peradilan pidana yang ditujukan pada penguatan prinsip independensi pengadilan. Reformasi peradilan secara substansial telah berhasil menempatkan lembaga pengadilan sebagai pelaksana kekuasaan kehakiman yang independen, yaitu dengan desain sistem penegakan hukum yang bertumpu pada one roof system (sistem satu atap/ sistem atap tunggal), dengan puncak kekuasaan kehakiman di Mahkamah Agung. Sistem penegakan hukum atap tunggal ini, secara konseptual memberikan jaminan "kekuasaan kehakiman yang merdeka", lepas campur tangan kekuasaan ekstra judisial.

Judicial Corruption yang melibatkan para penegak hukum telah menghambat laju reformasi peradilan, dalam usaha pembaharuan institusi peradilan, merusak independensi dan imparsialitas pengadilan, menurunkan tingkat kepercayaan masyarakat terhadap lembaga peng- adilan. Apabila konsisten dengan tujuan reformasi pengadilan yang telah memperkuat prinsip independensi dan imparsialitas pengadilan dalam konstitusi dan peraturan perundang-undangan, seharusnya tidak akan ditemukan judicial corruption. Kenyataan membuktikan lain, bahwa judicial corruption yang kemudian dikenal sebagai "mafia peradilan", bahkan telah menjadi "ikon" tindakan menyimpang dalam proses peradilan pidana. Mafia peradilan merupakan jejaring illegal antar para pihak yang terlibat dalam pelaksanaan peradilan pidana, dijalankan secara sistemik transaksional yang bertujuan mencari keuntungan materi dengan menyamarkan penyalahgunaan hukum dalam batasan-batasan kekuasaan peradilan, yaitu para penegak hukum dengan pihak lain yang terlibat dalam penyelenggaraan peradilan pidana.

Praktik mafia peradilan yang melibatkan para penegak hukum dengan pihak yang berperkara, pada umumnya berorientasi pada keuntungan finansial dengan kompensasi penyalahgunaan kekuasaan publik (illegal abuse of public power). Proses interaksi antar para pihak yang terlibat mafia peradilan berdasarkan logika transaksional yaitu mempertukarkan barang dengan jasa sebagai komoditi. ${ }^{15}$ Gejala suap menyuap sebagai bentuk praktik mafia peradilan, secara teoritis bisa dijelaskan dengan teori pertukaran (exchange theory) dari Peter M. Blau. Titik awal teori pertukaran ialah pertukaran barang-barang dan jasa, yang menekankan pada pentingnya norma-norma "reciprocity" (norma pertukaran). Menurut Peter Blau, dalam in-teraksi para pihak yang berkepentingan, ketika terjadi ketimpangan pertukaran, maka perbedaan kekuasaan akan muncul dalam asosiasi para pihak yang berinteraksi. ${ }^{16}$

Peter M. Blau lebih lanjut menyatakan bahwa dalam hubungan sosial terdapat hubungan ketergantungan antar pihak berdasarkan

15 Susetiawan, "Masyarakat Indonesia Dalam Bingkai Perubahan Dialektis", Jurnal Mimbar Hukum Fakultas Hukum UGM. 2007 hlm. 135.

16 Peter M. Blau dalam George Ritzer \& Douglas J. Goodman, 2009, Teori Sosiologi, Dari teori Sosiologi Klasik, sampai Perkembangan Mutakhir Teori Sosial Post Modern, Cet. Ketiga, Penerjemah Inyiak Ridwan Muzir. Yogjakarta: Penerbit Kreasi Wacana, hlm. 459. 
perbedaan kekuasaan dan konsekuensi materi. Hubungan yang tidak seimbang dalam penguasaan kekuasaan, pihak yang lebih berkuasa akan dapat memaksakan kehendak dan kepentingannya kepada pihak lain ketika berhubungan secara sosial. Kekuasaan tersebut dapat dipertukarkan untuk menghasilkan hubungan sosial yang relatif setara dengan imbalan materi. Ketika satu pihak dalam hubungan sosial memerlukan sesuatu dari pihak lainnya, tidak memiliki sesuatu yang sebanding untuk ditawarkan, tersedia empat alternatif. Pertama, orang dapat memaksa orang untuk membantunya; kedua, mencari sumber lain untuk mencari apa yang diperlukan; ketiga, mereka terus menjalaninya, meskipun tanpa sesuatu yang diperlukan dari orang lain; dan keempat, ini yang terpenting, mereka dapat meletakkan diri mereka pada posisi yang lebih rendah dari orang lain, sehingga memberikan "nilai umum" kepada orang lain dalam hubungan sosial yang dijalani, selanjutnya orang lain dapat menarik kembali penilaian tersebut ketika mereka ingin melakukan sesuatu (alternatif terakhir ini, tentu saja, merupakan ciri terpenting dari kekuasaan).

Berdasarkan hasil penerapan teori pertukaran, terlihat bahwa penetapan dari suatu rancangan "reciprocity" akan memberikan suatu kesempatan untuk menghindarkan strukturstruktur hukum yang membeku dan membantu yang akan dapat, di dalam beberapa wilayah social life, memudahkan proses-proses ekonomi. Konsekuensi negatif dari proses-proses ekonomi yang bersifat "negatif", yaitu berhubungan proses pengkaratan (corrosion) dari sistem hukum yang berlangsung secara sistematis dan konstan akibat adanya serangan dari perilaku, dimana perilaku tersebut menggunting prestise dari sistem hukum tersebut. Situasi sulit, antara lain berupa black-mail (pemerasan) dan "keharusan" untuk mengeluarkan uang suap, semua ini telah dianggap sebagai sesuatu yang secara informal harus diterima sebagai sesuatu yang umum dan dijadikan pola-pola struktural operasional dari perilaku-perilaku yang terkoordinasi.

Suap menyuap aparat peradilan dapat dijelaskan dengan teori pertukaran kekuasaan dari Peter M. Blau, bahwa aparat penegak hukum diposisikan sebagai pihak yang mempunyai kekuasaan besar, sedang pihak terdakwa pihak yang lemah kekuasaan. Dalam proses hukum terjadi interaksi sosial yang mendekatkan dua kepentingan, yaitu aparat penegak hukum dan terdakwa, interaksi dua kepentingan bertemu dalam hubungan resiprositas (reciprocity relation), pada akhirnya terjadilah hubungan pertukaran kekuasaan, yaitu pertukaran antara kekuasaan yang dimiliki penegak hukum berupa kewenangan hukum (jasa) dengan kekuasaan terdakwa berupa materi (uang/barang). Secara strukural operasional muncullah pertukaran barang dengan jasa.

Telaah teortis terhadap gejala " mafia peradilan" sebagaimana telah dibahas berdasarkan teori pertukaran (exchange theory) dari Peter M. Blau di atas, juga bisa dijelaskan dalam konteks Lembaga Peradilan Pidana dengan menggunakan teori integrasi dari Harry .C. Bredemeier. Teori yang dikembangkan Bredermeier merupakan derivasi dari teori sibernetik Talcot Parson. Bertolak dari kerangka Talcot Parsons, Bredermeier menggambarkan bagaimana proses pertukaran (interchange) antara sub-sub sistem dalam kerangka Parsons. Dibawah ini dijelaskan dalam bentuk bagan supaya lebih jelas: ${ }^{17}$
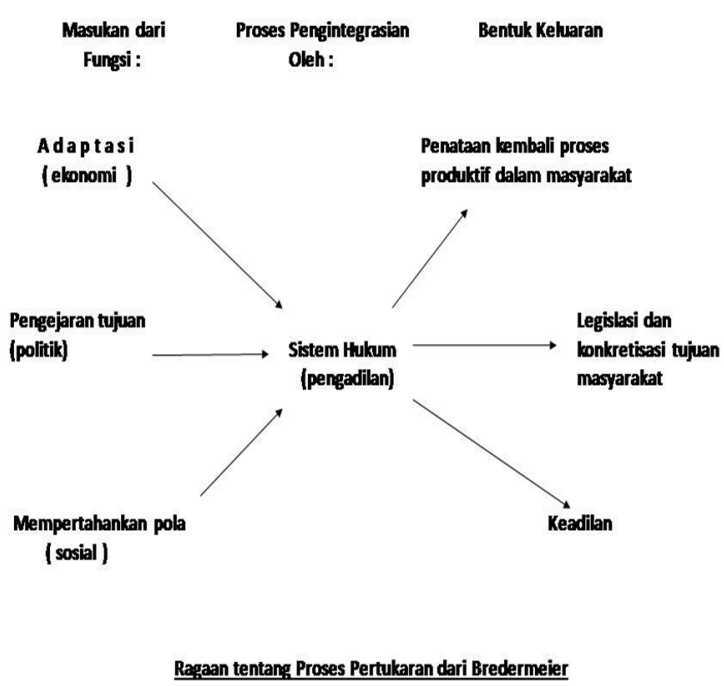

17 Lihat dalam Satjipto Rahardjo, 1982, IImu Hukum, Bandung: Alumni, hlm. 39-40. 
Bredermeier berusaha menjelaskan teorinya dengan melakukan analisis bagaimana hukum saling berinterelasi dengan pattern variables yang ada dalam sistem sosial masyarakat. Pattern variables dalam sistem sosial meliputi pattern variable of adaption (economy, science, and technology), pattern variable of goal pursuance (polity) dan pattern maintenance (society) yang mempunyai fungsi pemeliharaan eksistensi sistem sosial. Sebaliknya posisi hukum merupakan out put dari solidaritas sosial dari hasil interpretasi terhadap rasa keadilan. Integrasi antar pattern variable dalam sistem sosial dengan out put berupa hukum, pada dasarnya memposisikan hukum melakukan konkretisasi bentuk-bentuk struktur peran, tugas dan kewajiban, tetapi efisiensi dari dari proses konkretisasi tergantung kepada goal structure yang dimiliki masyarakat, serta kemampuan masyarakat untuk mendayagunakan seluruh potensi yang ada dalam hukum yang dimilikinya.

Proses integrasi antar pattern variable sistem sosial tergantung dari hukum yang merupakan ilmu tentang fungsi dari berbagai jenis perilaku. Persoalan tentang intensitas fungsi hukum dalam menjalankan integrasi, sesungguhnya berada di luar hukum sebagai sistem normatif, sehingga solusi atas permasalahan tersebut hanya bisa dijelaskan dari kekuatan pattern variable yang melingkupinya. Interrelasi antar pattern variable akan menggambarkan bagaimana hubungan sosial sebagai sistem sosial bisa berfungsi mengatur satu sistem sosial tertentu. Integrasi antara pattern variable akan menciptakan suatu mekanisme tertentu untuk mencapai tujuan dalam sistem sosial. Hukum berperan untuk melakukan interpretasi respon-respon dari polity enforcement procedure, akan tetapi apabila akan menerapkan kebijakan hukum berdasarkan goal pursuance kasus-kasus individu, diperlukan pengetahuan bentuk hubungan sosial yang terjadi dan mungkin akan merintangi penerapan kebijakan tersebut. Hukum dalam menjalankan fungsinya, akan membentuk organisasi dalam masyarakat dan kemampuan inilah yang menjadi ciri utama hukum yang disebut adaptive process.
Terjadinya proses hukum yang koruptif, yang lazim disebut mafia peradilan, pada dasarnya merupakan hasil dari interelasi antar para pihak dengan latar belakang yang beragam, serta dibedakan dari aspek jabatan dan kewenangan, kemampuan materi ekonomi, kekuasaan politik. Berdasarkan teori pertukaran kekuasaan (exchange theory) dari Peter M. Blau dan teori intergrasi dari Harry. C. Bredemeier, serta bertolak dari peristiwa pertukaran (exchange) antar sub sistem sosial, dengan latar belakang ekonomi, politik dan sosial. Pertukaran antar sub sistem sosial tersebut, bisa berubah menjadi kriminogen, apabila dimotivasi tindakan menyimpang untuk memenuhi kepentingan bersama antar pihak-pihak, dengan mengorbankan dan mengabaikan tujuan umum dari sistem sosial, yaitu keadilan, legalitas hukum dan ketertiban yang tercakup dalam sistem sosial.

Praktik mafia peradilan pada hakikatnya merupakan tindakan yang merusak sistem sosial dan menghasilkan out put hukum yang tidak adil. Mafia peradilan yang dilakukan secara sistematis oleh para penegak hukum merupakan pengabaian secara sengaja dan terencana terhadap sistem penegakan hukum yang sudah baku dalam mekanisme dan prosedur. Penggerogotan dan perusakan terhadap sistem penegakan hukum, tidak hanya pada sistem prosedural (procedural/physical system), tetapi juga merusak dan mengabaikan sistem tata nilai (value system) berupa asas-asas hukum yang adil, kedua sistem tersebut tercakup dalam sistem due process of law.

Praktik mafia peradilan merupakan perbuatan melanggar hukum dan melanggar sistem nilai (moralitas) dalam peradilan pidana. Pelanggaran terhadap prinsip-prinsip dasar proses hukum yang adil (due process of law) menimbulkan proses hukum yang sewenang-wenang (arbitrary process). Praktik suap penegak hukum telah merusak sistem prosedur dan sistem nilai. Akibat praktik mafia peradilan, terjadi penyimpangan dan pelanggaran prosedur baku dan melanggar nilai-nilai moralitas yang ada dalam asas penegakan hukum due process of law. Carut marut penegakan hukum pidana da- 
Iam kasus Gayus misalnya, berdasarkan hasil Eksaminasi Kejagung ditemukan "Ketidakcermatan yang disengaja" yaitu pelanggaran proses dan prosedur penuntutan, sehingga Penuntut Umum dan J aksa Peneliti dianggap melakukan kecerobohan yang berakhir dengan bebasnya terdakwa karena Surat Dakwaan tidak bisa dibuktikan. Penyalahgunaan kekuasaan publik oleh penegak hukum untuk memperoleh keuntungan materi, pada hakikatnya telah sengaja "memperdagangkan hukum". Hukum menjadi komoditi bisnis, masuk dalam permasalahan sebagai "pertukaran antara penawaran dan permintaan". Urusan hukum tidak lagi menjadi urusan moral, yang menyebabkan masyarakat (pencari keadilan) tidak bisa mengelak dari tarikan ekonomi, menyebabkan gangguan moralitas hukum semakin berambah besar terhadap hukum, khususnya penegakan hukum pidana ${ }^{18}$.

\section{Reformasi Sistem Peradilan Pidana dan Usaha Penanggulangan Mafia Peradilan}

Peradilan pidana merupakan bagian penting dalam usaha penanggulangan kejahatan dengan sarana hukum pidana. Peradilan pidana bekerja dalam suatu sistem penegakan hukum pidana yang bersifat terpadu, menitikberatkan pada keterpaduan sistem, sehingga lazim disebut Sistem Peradilan Pidana. Keterpaduan dalam sistem peradilan pidana dimaksudkan agar proses peradilan berjalan secara efektif dan efisien, saling menunjang antar penegak hukum dalam menemukan hukum dan menerapkan yang tepat untuk menjamin kepuasan pencari keadilan yaitu mewujudkan keadilan dalam kesadaran kenyataan hukum masyarakat. ${ }^{19}$

Apabila peradilan pidana dipahami dari aspek pendekatan sistem hukum, maka bekerjanya peradilan pidana sangat teragantung dari sinkronisasi dan harmonisasi dari komponen peradilan pidana, yaitu sub sistem penyidikan, sub sistem penuntutan, sub sistem pengadilan

18 Kamri Ahmad, "Membangun Visi Baru: Pemberantasan Korupsi dengan Hukum Progresif", J urnal Hukum Progresif, Vol 1/No 2 Oktober 2005. PDIH UNDIP. Semarang, hlm. 133.

19 Hafrida, "Sinkronisasi Antar Lembaga Penegak hukum dalam Mewujudkan Sistem Peradilan Pidana yang Terpadu", J urnal Hukum Forum Cendekia, Vol 18 No. 2 Oktober 2008, hlm. 66 dan sub sistem pelaksanaan putusan pengadilan yaitu Lembaga Pemasyarakatan. Praktik mafia peradilan, pada hakikatnya adalah perbuatan sistematis yang merusak sistem dalam peradil-an pidana. Rusaknya sistem peradilan pidana, pada dasarnya bisa bersumber dari sistem prosedural (procedural/physical system) dan sistem nilai (values system). Kedua komponen ini akan runtuh apabila salah satu mengalami serangan yang merusak. Perilaku penegak hukum yang menerima uang suap merupakan tindakan merusak komponen kultur hukum (legal culture), akibatnya penegak hukum yang mengabaikan asas-asas peradilan yang baik, juga merusak sistem interaksi yang sudah baku standarnya, yang terjadi kemudian adalah carut marut penegakan hukum pidana. Penegak hukum yang terlibat mafia peradilan, menukar kewenangan hukum dengan keuntungan materi.

Sistem peradilan pidana sering diartikan secara sempit sebagai sistem pengadilan yang menyelenggarakan keadilan atas nama negara atau sebagai mekanisme untuk menyelesaikan suatu perkara/ sengketa. Dalam arti sempit, peradilan pidana hanya melihat aspek struktural (yaitu "system of court" sebagai institusi) dan hanya melihat aspek kekuasaan mengadili/menyelesaikan perkara (administration justice/ mechanism for the resolution of disputes). Peradilan pidana sebagai sistem mencakup dua aspek, yaitu aspek struktur institusi yang melibatkan beberapa instansi penegak hukum dan aspek nilai, yaitu asas-asas penegakan hukum pidana yang tercakup dalam due process of law. Interaksi antar instansi penegak hukum dalam mekanisme proses peradilan mencakup rantai kewenangan sistem peradilan pidana.

Secara konseptual, inti dan arti penegakan hukum terletak pada kegiatan menyerasikan hubungan nilai-nilai yang dijabarkan dalam kaidah-kaidah yang mantab dan mengejawantah serta sikap tindak sebagai rangkaian penjabaran nilai tahap akhir, untuk menciptakan, memelihara dan mempertahankan kedamaian dan ketertiban masyarakat. ${ }^{20}$ Substansi nilai meru-

\footnotetext{
20 Hibnu Nugroho, "Optimalisasi Penegakan Hukum Dalam
} penanggulangan Kejahatan Global di Indonesia", Jurnal 
pakan fondasi filosofis dalam rangka memperkuat asas-asas penegakan hukum yang adil (due process of law), sebaliknya konsep penegakan hukum yang lebih menekankan pada pendekatan sistem yang kaku dan prosedural, mengejar tujuan tetapi mengabaikan aspek kemanusiaan dan tujuan hukum yaitu mewujudkan keadilan. Hukum adalah alat yang digunakan untuk menegakkan nilai-nilai kemanusiaan, bukan hanya sebatas pemenuhan prosedur hukum yang kaku, tetapi untuk menjunjung tinggi nilai kemanusiaan, karena sesungguhnya hukum adalah untuk manusia. ${ }^{21}$

Penegakan hukum pidana yang dijalankan berdasarkan konsep penegakan hukum sama dengan penegakan undang-undang, memberikan peluang penyalahgunaan kekuasaan, yaitu tindakan hukum yang sewenang-wenang (arbitrary process of law). Hukum dijalankan dalam mekanisme dan prosedur yang kaku, mengabaikan unsur nilai kemanusiaan. Pertimbangan kemanusiaan menjadi berkurang, umumnya pada tindakan hukum penggunaan upaya paksa seperti penangkapan dan penahanan. Penegakan hukum berdasarkan wewenang tidak keliru, tetapi menjadi kurang manusiawi apabila dipergunakan secara berlebihan. Untuk peningkatkan kua-litas penegakan hukum yang berorientasi pada spirit due process of law, maka perlu melakukan reformasi peradilan pidana.

Reformasi sistem penegakan hukum pidana yang bersifat integral, dimulai dengan melakukan reformlasi dan rekonseptualisasi "kekuasaan kehakiman" dan "desain penerapan kekuasaan kehakiman". Kekuasaan kehakiman di bidang hukum pidana bukan hanya diwujudkan dalam "kekuasaan mengadili", tetapi diwujudkan/ diimplementasikan dalam keseluruhan proses peradilan pidana, yaitu tahap penyidikan, penuntutan, sidang pengadilan dan pelaksanaan

Media Hukum, UMY Yogyakarta Vol XVII No 4 Desember 2007, hlm. 517

21 Secara garis besar bekerjanya hukum di masyarakat ditentukan beebrapa faktor, yaitu faktor juridis normatif (UU), penegak hukum, faktor juridis sosiologis, yaitu aspek ekonomi dan kultur hukum. Lihat Yohanes Suhardin. 2009. Penegakan Hukum yang Berkeadilan Sosial dan Berdimensi HAM (Studi Penggusuran Kelompok Marginal), J urnal Media Hukum UMY Yogyakarta, Vol 16 No. 3 putusan pengadilan. Keseluruhan proses peradilan pidana yang melibatkan lembaga-lembaga penegak hukum tersebut lazim dikenal dengan istilah "sistem peradilan pidana yang terpadu" (integrated criminal justice system).

Menata ulang "kekuasaan kehakiman" dalam proses peradilan pidana menjadi penting, karena pemberian kekuasaan kehakiman yang hanya tertuju kepada pengadilan menjadi titik lemah dalam sistem peradilan itu sendiri. Hal ini berkaitan dengan definisi dan ruang lingkup "kekuasan kehakiman" sebagaimana tersebut dalam Pasal 1 ayat (I) UU No. 48 Tahun 2009 Tentang Kekuasaan Kehakiman, sebagai kekuasaan negara yang merdeka untuk menyelenggarakan peradilan guna menegakkan hukum dan keadilan. Kekuasaan kehakiman sebagai kekuasaan negara yang merdeka, akan sangat menentukan kualitas, kredibilitas, dan integritas keseluruhan proses peradilan. Lembaga yang mempunyai kekuasaan kehakiman hanya lembaga pengadilan, maka hanya lembaga pengadilan yang bersih dan kebal (clean and immune) dari segala campur tangan pihak kekuasaan ekstra judisial, sedangkan lembaga penyidik, penuntut umum, dan lembaga pemasyarakatan menjadi rentan dan rawan intervensi kekuasaan ekstra judicial dan penyalahgunaan kekua-saan publik (illegal abuse of public power).

Usaha mengatasi kelemahan hukum dalam pengaturan kekuasaan kehakiman menurut Barda Nawawi Arief, ${ }^{22}$ ada dua kemungkinan yang dapat ditempuh. Pertama, membuat perundang-undangan baru atau merevisi ketentuan perundang-undangan yang berlaku saat ini dengan menegaskan pejabat mana yang dipandang sebagai "pejabat pengendali" itu. Kedua, kekosongan perundang-undangan itu diisi lewat yurisprudensi. Dalam hal pertama, bahwa Mahkamah Agung-lah yang ditetapkan sebagai "pejabat pengendali". Alasannya, menurut Pasal 24 UUD 1945, Mahkamah Agung-lah yang melaksanakan fungsi "Kekuasaan Kehakiman". Pengertian "kekuasaan kehakiman" seyogianya

\footnotetext{
22 Barda nawawi Arief, 1998, Beberapa Aspek Penegakan dan Pengembangan Hukum Pidana, Bandung: PT. Citra Aditya Bakti, hlm. 33
} 
tidak hanya diartikan sebagai "kekuasaan mengadili", tetapi lebih luas lagi, yaitu sebagai "kekuasaan untuk menegakkan hukum dan undang-undang. Apabila kekuasaan kehakiman di artikan secara luas, maka Mahkamah Agung tidak hanya berfungsi mengawasi penegakan hukum oleh badan-badan pengadilan, tetapi juga mengawasi seluruh proses penegakan hukum yang dilakukan mulai proses penyidikan, penuntutan, sampai pada putusan pengadilan dijatuhkan dan dilaksanakan/ dieksekusi.

Penataan kembali "kekuasaan kehakiman" dalam rangka menjalankan "kekuasaan penegakan hukum", yang memberikan kedudukan Mahkamah Agung sebagai otorita tunggal dalam penyelenggaraan kekuasaan kehakiman yang merdeka dan mandiri, mampu mengintegrasikan keseluruhan lembaga penegak hukum dalam menjalankan sistem peradilan pidana. Menempatkan Mahkamah Agung menjadi "pengawas dan pengendali puncak/tertinggi (the top leader atau the top law enformcement officer) dari keseluruhan proses penegakkan hukum pidana (mulai tahap penyidikan, penuntutan, sampai pada proses mengadili, menjatuhkan putusan/pidana dan eksekusi pidana). Adanya "pengendali puncak/tertinggi "ini merupakan konsekuensi logis dari manajemen SPP yang terpadu (integrated criminal justice system ). Tanpa adanya pengendali puncak, dikhawatirkan bekerjanya SPP bersifat "fragmentaris" atau "instansi sentries". ${ }^{23}$

Nilai-nilai dasar akuntabilitas publik dalam penegakan hukum, khususnya dalam upaya pemberantasan mafia peradilan, meliputi prinsip-prinsip, pertama adalah access to justice (akses kepada keadilan), pada proses hukum dan putusan; kedua adalah timelines of justice delivery (standar waktu untuk mencapai keadilan); ketiga adalah quality of justice delivery (kualitas keadilan dari penegak hukum dan putusan hakim); dan keempat adalah independence, impartiality and fairness of the judiciary (independensi, imparsialitas juga keterbukaan dari kekuasaan peradilan); kelima adalah public trust in judiciary (kepercayaan masyarakat

23 Ibid. pada kekuasaan kehakiman/peradilan). ${ }^{24}$ Prinsip-prinsip di atas merupakan bagian dari arus besar globalisasi yang mensyaratkan prinsipprinsip Good Governance, seperti transparansi, keterbukaan, akuntabilitas publik, proporsionalitas dalam kegiatan organisasi.

Desain sistem atap tunggal kekuasaan kehakiman yang ditujukan pada spirit independensi peradilan tidak mempunyai arti sama sekali, bahkan terjadi distorsi makna kebebasan/ independensi peradilan. Independensi peradilan bisa dijalankan dan lepas dari campur tangan kekuasaan eksekutif dan legislatif, tetapi penegak hukum tidak mampu bertahan dari godaan materi dan uang yang berlimpah. Kekuatan materi dan uang mereduksi independensi peradilan dan terjerumus dalam mafia peradilan dengan modus operandi menyalahgunakan kekuasaan (illegal ab-se of publik power). Makna kebebasan peradilan perlu dikoreksi dalam konteks yang lebih proporsional, yaitu "keseimbangan antara prinsip kebebasan peradilan dan akuntabilitas", agar setiap produk penegakan hukum "membumi", diterima masyarakat dan dipercaya sebagai lembaga negara yang menjalankan monopoli peradilan pidana. Kondisi yang diinginkan hukum hanya dapat terwujud apabila hukum ditopang penegak hukum yang terampil, tetapi juga bermoral dan berdedikasi tinggi ${ }^{25}$

Keberadaan Komisi Yudisial bertujuan untuk menampung keluhan masyarakat pencari keadilan yang diperlakukan tidak adil dalam proses hukum. Untuk menjalankan fungsi kontrol terhadap kinerja pengadilan, KY dan MA, berdasarkan UU. No. 3 Tahun 2009 tentang MA, dibentuk Majelis Kehormatan Hakim (MKH) yang masih bersifat ad hoc, dengan komposisi anggota 3 nama berasal dari MA dan 4 nama dari $\mathrm{KY}$. MKH adalah sarana institusi kontrol terhadap perilaku hakim secara internal peradilan. MKH dibentuk untuk mengambil keputusan terhadap pelanggaran kode etik dan perilaku Ha-

\footnotetext{
24 Bambang Wijoyanto, op. cit, hlm. 3.

25 Mahmutarom HR, "Pembangunan Hukum Nasional dalam Konteks Global", Jurnal Masalah-Masalah Hukum, FH UNDIP, Semarang, 2006, hlm. 86.
} 
kim dengan hukuman pemberhentian secara tidak hormat atau pemberhentian sementara.

Untuk memperkuat akuntabilitas peradilan di masyarakat, beberapa NGO (non government organization), seperti ICW, TII, MaPPI FH UI, beberapa Perguruan Tinggi melakukan Eksaminasi Publik terhadap putusan pengadilan yang terindikasi praktik mafia peradilan. Peran serta masyarakat dalam pengawasan kinerja penegak hukum dalam pemberantasan korupsi, dapat dilakukan dengan membangun gerakan massa anti korupsi (critical mass) terutama di jalankan NGO sebagai kekuatan pedobrak (social movement) seluruh masyarakat memperkuat nilai-nilai dan institusi demokrasi dan supremasi si-pil. ${ }^{26}$ Penguatan prinsip akuntabilitas publik atas putusan pengadilan dapat dilakukan masyarakat sebagai partisipasi pengawasan sistem peradilan pidana sejalan dengan spirit transparansi dan akuntabilitas publik. Partisipasi masyarakat dalam mengawasi kinerja lembaga peradilan pada dasarnya menjadi bagian dalam reformasi sistem peradilan pidana dalam ber-bagai peraturan perundang-undangan. Bahkan pada era teknologi informasi ini, pola pengawasan masyarakat terhadap kinerja peradilan akan lebih mudah dan efektif dengan dukungan perangkat teknologi informasi. ${ }^{27}$

\section{Penutup \\ Simpulan}

Praktik mafia peradilan berlangsung dalam proses peradilan pidana secara sistemik, melibatkan penegak hukum dan pihak lain. Formalitas hukum digunakan untuk pembenaran transaksional bermotif keuntungan materi dengan mengorbankan nilai-nilai keadilan menjadi pola perilaku yang permisif karena desain sistem peradilan pidana masih bersifat parsial sehingga kontrol dan pengawasan terhadap peradilan masih lemah.

26 George Aditjondro, 'Dialektika antara Agency dengan Struktur dalam Pemberantasan Korupsi di Indonesia", Renai, J urnal Kajian Politik Lokal dan Studi Humaniora, Tahun VII No 2 2007, Yayasan Percik, Salatiga, hlm. 9.

27 Agus Raharjo, Sunaryo dan Nurul Hidayat, "Pendayagunaan Teknologi Informasi dalam Pemberdayaan Masyarakat Untuk Mengawasi Sistem Peradilan Pidana di Jateng", Jurnal Dinamika Hukum, Vol 10 No 3 September 2010, FH UNSOED Purwokerto hlm. 206-207.
Reformasi sistem peradilan pidana dari aspek substansi hukum tercakup dalam desain kekuasaan kehakiman one roof system masih bersifat parsial, karena belum meliputi lembaga penyidik dan penuntut umum, hanya pada badan-badan pengadilan. Reformasi sistem peradilan pidana dapat dilakukan dengan desain sistem peradilan pidana yang integral berpuncak pada Mahkamah Agung sebagai top leader kekuasaan kehakiman yang bisa mengontrol keseluruhan praktik penegakan hukum termasuk penyidik dan penuntut umum sebagai bagian kekuasaan kehakiman serta aspek kultur hukum dengan menegakkan perilaku penegak hukum menj unjung tinggi asas due process of law.

\section{Saran}

Usaha penanggulangan mafia peradilan bisa dilakukan dengan desain kekuasaan kehakiman yang meliputi keseluruhan lembaga penegak hukum yaitu penyidik, penuntut umum, hakim dan pelaksana putusan pengadilan sebagai institusi kekuasaan kehakiman yang berpuncak pada Mahkamah Agung sebagai top leader kekuasaan kehakiman. Pengawasan yang ketat dan penerapan sanksi berat pada pelaku mafia per-adilan menjadi pilihan untuk menanggulangi praktik mafia peradilan.

Usaha menanggulangi praktik mafia peradilan yang bersumber dari perilaku menyimpang, bisa dimulai dengan penguatan kultur hukum yaitu menegakkan kode etik profesi penegak hukum. Penegakan kode etik profesi penegak hukum akan lebih efektif apabila dilaksanakan dalam sistem peradilan pidana dalam desain kekuasaan kehakiman yang meliputi keseluruhan lembaga pendukung sistem peradilan pidana yang berpuncak pada Mahkamah Agung sebagai Top Leader dalam penegakan kode etik profesi penegak hukum.

\section{Daftar Pustaka}

Aditjondro, George. "Dialektika antara Agency dengan Struktur dalam Pemberantasan Korupsi di Indonesia". Renai, J urnal Kajian Politik Lokal dan Studi Humaniora, Tahun VII No 2 2007. Yayasan Percik, Salatiga; 
Ahmad, Kamri. "Membangun Visi Baru: Pemberantasan Korupsi dengan Hukum Progresif". J urnal Hukum Progresif, Vol 1/ No 2 Oktober 2005. PDIH UNDIP. Sema-rang;

Arief, Barda Nawawi. 1998. Beberapa Aspek Penegakan dan Pengembangan Hukum Pidana. Bandung: PT. Citra Aditya Bakti;

Daradono, Donny. "Uang, Ideologi, Jabatan daIam Mafia Peradilan, Reduksi terhadap The Political". Renai, Jurnal Kajian Politik Lokal dan Studi Humaniora. Tahun VII No 2 Tahun 2007. Yayasan Percik Salatiga;

Hafidz, Jawade. "Sistem Pertanggungjawaban Perkara Korupsi Dalam Percepatan Penyelematan Keuangan Negara". Jurnal Dinamika Hukum Vol 11 Edisi Khusus Februari 2011. FH UNSOED;

Hafrida. "Sinkronisasi Antar Lembaga Penegak hukum dalam Mewujudkan Sistem Peradilan Pidana yang Terpadu". J urnal Hukum Forum Cendekia, Vol 18 No. 2 Oktober 2008;

$\mathrm{HR}$, Mahmutarom. "Pembangunan Hukum Nasional dalam Konteks Global". Jurnal Masalah-Masalah Hukum, 2006 FH UNDIP;

Ibrahim, Anis. "Hukum Progresif: Solusi atas Keterpuruk-an Hukum Indonesia", J urnal Hukum Progresif, Vol 2 No. 1/ April 2006 PDIH Undip Semarang;

Indah S, C. Maya. "Refleksi sosial atas Kelemahan hukum Modern, suatu diseminasi hukum tradional dalam citra hukum Indonesia". J urnal Masalah-Masalah Hukum, Vol 103 No. 37 Tahun 2008. FH UNDIP;

Mardin, Nurhayati. "Makna Kepala Putusan Pengadilan: Keadilan Berdasarkan Ketuhanan Yang Maha Esa (Tinjauan Rechtphilosopie)". Jurnal Hukum Aktualita. Vol II No 3 Desemebr-Maret 2007, FH Universitas Tadulako;

Muquddas, Busryo. Mafia Peradilan Berjalan Sistemik. Lihat dalam http:// beritasore. com/ 2009/ 07/ 16/ mafia-peradilan.

Diunduh 12 juli 2011;

Nugroho, Hibnu. "Optimalisasi Penegakan Hukum Dalam penanggulangan Kejahatan Global di Indonesia". Jurnal Media Hukum, Vol XVII No 4 Desember 2007. UMY Yogyakarta;

Rahardjo, Satjipto. 1982. Ilmu Hukum, Bandung: Alumni;
Raharjo, Agus. Sunaryo dan Nurul Hidayat. "Pendayagunaan Teknologi Informasi dalam Pemberdayaan Masyarakat Untuk Mengawasi Sistem Peradilan Pidana di J ateng". J urnal Dinamika Hukum, Vol 10 No 3 September 2010, FH UNSOED;

Rifai, Edy. "Peran Hakim Dalam Penemuan Hukum dan Menciptakan Hukum Pada Era Reformasi". Jurnal IImu Hukum "Praevia". Vol. 4. No. 1 tahun 2010. FH Unila;

Ritzer, George \& Douglas J. Goodman, 2009, Teori Sosiologi, Dari Teori Sosiologi Klasik, sampai Perkembangan Mutakhir Teori Sosial Post Modern. Cet. Ketiga, Penerjemah Inyiak Ridwan Muzir. Yogjakarta: Penerbit Kreasi Wacana;

Said, Noor Aziz. "Rekonstruksi Pertanggungjawaban Pidana terhadap Tindak Pidana Korupsi APBD yang Dilakukan Anggota Dewan". Jurnal Dinamika Hukum. Vol. 11 Edisi Khusus. Februari 2011. FH UNSOED, Purwokerto:

Santoso, M. Edi. "Kebijakan Pidana Dalam Proses Gerakan Sosial Melalui Sistem Peradilan Pidana terhadap Mafia Peradilan". J urnal Gema, Vol XVIII. No 33 Tahun 2005. Universitas Islam Batik, Surakarta;

Suhardin, Yohanes. "Penegakan Hukum yang Berkeadilan Sosial dan Berdimensi HAM (Studi Penggusuran Kelompok Marginal)", J urnal Media Hukum Vol 16 No.3. UMY Yogyakarta;

Susetiawan. "Masyarakat Indonesia Dalam Bingkai Perubahan Dialektis". J urnal Mimbar Hukum. 2007. Fakultas Hukum UGM;

Syamsudin, M. "Faktor-Faktor Sosio-legal yang Menentu-kan Dalam penanganan Perkara Korupsi di Pengadilan". Jurnal Media Hukum. 2010. UMJ . Yogyakarta;

------.. "Rekonstruksi Pola Pikir Hakim dalam Memutus Perkara Korupsi Berbasis Hukum Progresif". Jurnal Dinamika Hukum, Vol 11 No $1 \mathrm{~J}$ anuari 2011, FH UNSOED;

Widjojanto, Bambang. "Harmonisasi Peran Penegak Hukum Dalam Pemberantasan Korupsi". Jurnal Legsilasi Indonesia, Vol 4 No. 1 Maret 2007. Direktorat Jenderal Perundang-undangan Depkumham Rl;

Wiriadinata, Wahyu. "Masalah Mafia Peradilan dan Korupsi di Indonesia". Jurnal Syiar Hukum, Vol XIL No 1 Maret 2010. Fakultas Hukum Universitas Islam Bandung. 